\title{
PRESENT EFFECTS OF PAST WILDFIRES ON LEAF LITTER BREAKDOWN IN STREAM ECOSYSTEMS
}

\author{
Peter Koetsier ${ }^{1}$, Teresa R. B. Krause ${ }^{2}$, and Quenton M. Tuckett ${ }^{3}$
}

\begin{abstract}
We investigated the present effects from a 10-year-old wildfire on leaf litter breakdown rates in 3 headwater streams in central Idaho. These systems experienced a massive debris flow one year after the fire. Based on soil instability and burn patterns, we identified 3 stream conditions: unburned, burned only, and burned/scoured. We placed leaf bags containing willow leaves (Salix sp.) in each stream type and removed bags at various time intervals until all bags were collected 100 days after their introduction. Leaf material was dried and weighed, and decay rate coefficients were calculated. Macroinvertebrates colonizing the bags were enumerated and identified, and selected taxa were placed into trophic groups. We found that the unburned stream had the fastest leaf litter breakdown rate, the lowest level of incident light reaching the stream, and the largest amount of benthic organic matter. The burned/scoured stream was nearly opposite in all respects. Numbers of 2 detritivore invertebrate taxa, Serratella tibialis and Zapada oregonensis, were highest in the unburned stream but lowest in the burned/scoured stream. A third taxon, Baetis sp., showed the opposite relationship. Presence of predatory invertebrates did not affect detritivore abundance or leaf decay rate in the bags. Our research suggests that recovery response variables of some stream systems may not have returned to prefire levels even a decade after the initial wildfire. In this study, the recovery of our streams appears to be connected to the return of the riparian zone, though fire-induced debris flows may slow or alter final recovery of the stream system.
\end{abstract}

Key words: wildfire, streams, debris flows, leaf litter breakdown.

In the western United States, wildfire is a major natural disturbance affecting terrestrial landscapes and the streams that drain them. Because of the intimate link between a stream and its catchment, any perturbation in the drainage basin will influence the structure and function of a stream's biotic components (Hynes 1975, Vannote et al. 1980). Immediate (0-1-year) and short-term (1-10-year) effects of fire on stream ecosystems have been well documented (Minshall et al. 1997, 2004, Gresswell 1999), though these effects usually wane within a decade (Gresswell 1999, Robinson et al. 2005). Most research has focused on the stream's population, community, and physical-chemical responses to wildfire at various temporal scales: water chemistry at the immediate timescale (Spencer et al. 1991); fish and macroinvertebrate distributions (Mihuc and Minshall 1995, Minshall 2003, Dunham et al. 2007) and stream channel response in the short-term timescale (Minshall et al. 1997, 2004). To date, few studies have examined the effect wildfire has on ecosystem-level stream processes at any time range (but see Tuckett 2007).
Minshall et al. (1989) predicted that, due to loss of riparian vegetation and subsequent increases in light reaching the stream, primary production would increase and peak during the first 6 years after fire. In addition, detritial-based energy inputs (leaves, sticks, logs, etc.) would remain low until the riparian canopy grew back. Stream biota should attain prefire levels within the first 10 years after fire (Rieman and Clayton 1997, Minshall 2003, Vieira et al. 2004). However, long-term stream recovery (10-100 years) may ultimately be linked to recovery of riparian and terrestrial flora in the drainage basin (Minshall et al. 1989).

Recent studies show that, based on underlying geology, soil type, and burn intensity, some tributaries are prone to massive debris flows and channel reorganization when riparian vegetation is removed by fire (Benda et al. 2003, Dwire and Kauffman 2003, Wondzell and King 2003, Dunham et al. 2007, Tuckett 2007). Such debris flows may periodically reoccur under moderate to heavy rainfall events. In these streams, debris flows would continually retard riparian recovery, resetting the biotic community to an earlier successional stage. Consequently, debris flows

${ }^{1}$ Department of Biological Sciences, Boise State University, 1910 University Dr., Boise, ID 83725-1515.

${ }^{2}$ Department of Earth Sciences, Montana State University, 200 Traphagen Hall, Bozeman, MT 59717-3480.

${ }^{3}$ School of Biology and Ecology, University of Maine, 217 Murray Hall, Orono, ME 04469 
may delay recovery of the stream biota or move the assemblage to a new terminal state, different from that of the prefire condition (sensu Drake 1990).

One ecosystem-level process that may be affected by wildfire and subsequent debris flows is decomposition of coarse particulate organic matter (CPOM). In many forested headwater streams, the breakdown of leaf litter input contributes to particle transport, provides habitat for macro- and microinvertebrates, and constitutes the main source of energy driving the stream ecosystem (Vannote et al. 1980). Detrital decomposition is facilitated by both physical (current, substrate type, retention structures, etc.) and biological factors (microbial processing and macroinvertebrate feeding) (Webster and Benfield 1986). Leaf litter breakdown rate integrates the variability of these factors into a single response signature that can be used to compare stream ecosystems or measure the system's response to disturbance (Sponseller and Benfield 2001, Paul et al. 2006). Thus, a disturbance that alters either leaf litter inputs or the macroinvertebrate composition may affect CPOM breakdown and ultimately dictate the energy available to higher levels of the stream's food web.

In our research on stream recovery from wildfire (Koetsier et al. 2007, Tuckett 2007), we found that after 12 years, streams that burned and then experienced debris flows and channel reorganization were still significantly different from unburned and burned-only systems. Burned-then-scoured streams (burned/scoured) were autotrophic and had higher incident light levels, higher gross primary production, and lower ecosystem respiration (Tuckett 2007). Further, we found differences in macroinvertebrate community composition among these systems (Tuckett 2007). Given that past wildfires continue to influence the invertebrates and leaf inputs in stream systems, we hypothesized that we should also see differences in the rate of leaf litter decomposition. In this current study, we placed (and eventually retrieved) leaf bags in streams that were unburned (reference), burned only, and burned then scoured with debris flows a year after the fire.

\section{Methods}

\section{Study Area}

Our study was conducted on 3 third-order tributaries of the Boise River catchment, located in the southern forested subregion of the Idaho Batholith ecoregion $\left(44^{\circ} 10^{\prime}-44^{\circ} 20^{\prime} \mathrm{N}\right.$, $\left.115^{\circ} 30^{\prime} \mathrm{W}\right)$. In the Boise National Forest, these streams have hillside gradients ranging from $20^{\circ}$ to $40^{\circ}$ and are highly dissected. Upland vegetation is dominated by stands of ponderosa pine (Pinus ponderosa) and Douglas-fir (Pseudotsuga menziesii), while riparian vegetation is dominated by willow (Salix spp.), cottonwood (Populus spp.), and water birch (Betula occidentalis) — each type with an associated understory of mixed shrubs, grasses, and forbs. The regional climate is continental, with an average precipitation of $500 \mathrm{~mm}$ per year (Benda et al. 2003). The bedrock substrate in the basin is dominated by moderately to well-weathered coarsegrained quartz monzonite, typical of much of the Idaho Batholith. Soils are lithosols, with weakly developed A horizons ranging from 5 to $25 \mathrm{~cm}$ thick. These granitic, droughty soils have limited fertility and are highly erodible when vegetation is removed (Megahan 1983, Megahan and Ketcheson 1996).

\section{Fire History and Sampling Methods}

This research was part of an ongoing investigation of the effects of wildfire on stream trophic structure. Using aerial photographs, GIS layer maps, and information from an onthe-ground, field reconnaissance survey (Tuckett 2007), we attempted to locate streams that were similar in catchment area, slope, gradient, elevation, and discharge (Table 1). One stream, Beaver Creek (our unburned reference stream), has not experienced a wildfire in the past 100 years. Our survey suggested that the characteristics of Beaver Creek were fairly representative of most unburned headwater streams in the basin (Dunham et al. 2007, Tuckett 2007). Two other streams, Trapper and Hungarian creeks, were burned in the 1994 Idaho City complex of wildfires (over 28,000 ha consumed by the fire with $85 \%-100 \%$ of each stream's catchment burned; Dunham et al. 2007). Due to soil instability after vegetation removal, Trapper Creek experienced massive scouring (erosion and redeposition of bed material and channel reorganization throughout the stream's reach) in the following year. This event removed almost all of the above- and belowground riparian plant material. Subsequently, this stream continued to experience scouring and redeposition of bed material after moderate storm events. 
TABLE 1. Physical characteristics of the study streams during August 2004.

\begin{tabular}{llcccrr}
\hline \multicolumn{1}{c}{ Stream } & Condition & $\begin{array}{c}\text { Elevation } \\
(\mathrm{m})\end{array}$ & $\begin{array}{c}\text { Mean width } \\
(\mathrm{m})\end{array}$ & $\begin{array}{c}\text { Gradient } \\
(\%)\end{array}$ & $\begin{array}{c}\text { Catchment area } \\
\left(\mathrm{km}^{2}\right)\end{array}$ & $\begin{array}{c}\text { Discharge } \\
\left(\mathrm{m}^{3} \cdot \mathrm{s}^{-1}\right)\end{array}$ \\
\hline Beaver Creek & Unburned & 1332 & 1.9 & 4.6 & 14.2 & 0.05 \\
Hungarian Creek & Burned only & 1286 & 1.8 & 6.4 & 11.5 & 0.07 \\
Trapper Creek & Burned/Scoured & 1479 & 2.6 & 9.1 & 9.1 & 0.06 \\
\hline
\end{tabular}

From our reconnaissance survey, we found that, based on wildfire patterns and soil instability, these systems were good examples of 3 stream conditions found throughout the Boise River basin: (1) unburned (UB), streams that were not burned by fire within the last century; (2) burned only (BO), streams that though burned, retained much of the vegetation's belowground structures; and (3) burned/scoured $(\mathrm{B} / \mathrm{S})$, streams that less than a year after the fire experienced major erosion, movement, and redeposition of bed material, which removed most of the riparian belowground vegetative structures (see Benda et al. 2003 for a detailed fire history of this area).

Due to the inability of locating streams within each condition that were similar enough to serve as replicates, we were forced to use a pseudoreplicated experimental design. We attempted to minimize potential problems of pseudoreplication by locating experimental sections in each stream $\geq 100 \mathrm{~m}$ apart. Separating experimental sections by $100 \mathrm{~m}$ allowed us reasonable travel time between sections for sample retrieval. Furthermore, we were careful not to extrapolate our findings beyond our current study streams (sensu Hawkins 1986).

After walking along 2-3 km of each stream, we selected 3 experimental sections that were typical of each reach. In each section, we anchored 3 pieces of galvanized-metal hardware cloth $(56 \times 56 \mathrm{~cm})$ to the substrate using metal stakes. To each piece, we attached 7 leaf bags with flexible wire. Leaf bags were constructed of plastic mesh bags $(15 \times 15 \mathrm{~cm}, 1$ $\left.\mathrm{cm}^{2} \mathrm{mesh}\right)$. We weighed $10 \mathrm{~g}( \pm 0.05 \mathrm{~g})$ of freshly abscised willow leaves and inserted these leaves into each bag. We used the largest willow leaves available to prevent the leaves from washing through the mesh bags immediately upon stream deployment. On 7 July 2004, we introduced 63 leaf packs into each stream (21 leaf bags in each experimental section and 3 experimental sections per stream). We removed 3 bags from each experimental section on days (after introduction) 1, 10, 21, 28,
42, 56, and 100 (15 October 2004). To retrieve each leaf bag, we placed a fine-meshed net (mesh size: $250 \mathrm{~mm}$ ) immediately downstream of the pack, clipped the attachment wire, and gently placed the bag into the net. The leaf bag and the contents of the net were transferred to a plastic jar and preserved with $7 \%$ buffered formalin.

On days 42-44 (18-20 August 2004), we measured several physical attributes of the study streams to ascertain if visual field differences in stream condition could be quantified by physiochemical measurements. We measured photosynthetically active radiation (PAR), stream discharge, diel temperature ranges (over a 48hour period), and benthic organic matter entrained on the stream substrate. These measurements were taken in a $100-\mathrm{m}$ reach downstream from the last experimental section in each stream. To measure PAR, we used coordinates selected from a random number table to choose 50 points along and across the $100-\mathrm{m}$ reach. At each point, we measured the amount of radiation using a LI-COR quantum sensor (model LI-192SA) and light meter (model LI250). We placed the sensor $3 \mathrm{~cm}$ above the water's surface and measured PAR between 12:00 and 13:00 on cloudless days. To calculate stream discharge, we divided the cross section of the stream's channel into 20 cells. In each cell, a single-flow measurement was made at 6/10-depth below the water's surface. Discharge was calculated by summing the volume of water flowing through the area of each individual cell per unit time (Gordon et al. 2004). Also, we placed a temperature data logger in the stream and recorded water temperature every $30 \mathrm{~min}-$ utes over a 48 -hour period. To estimate benthic organic matter in each stream, we took 6 benthic samples, using a Surber sampler $\left(0.09-\mathrm{m}^{2}\right.$, $250-\mu \mathrm{m}$ mesh), from the $100-\mathrm{m}$ reach, placed the contents into sample jars, and preserved them in $7 \%$ buffered formalin until they could be processed in the laboratory.

In the laboratory, macroinvertebrates were hand sorted from leaf bag organic material, 


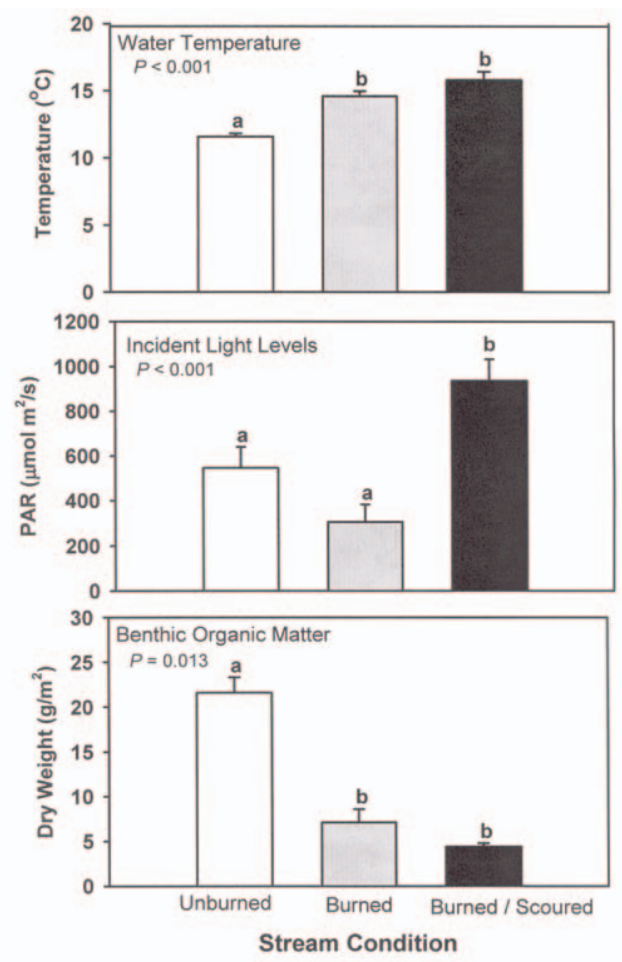

Fig. 1. Mean temperature $(n=48)$, incident light reaching the stream $(n=50)$, and benthic organic matter $(n=6)$ measured in the study streams on day 42 of the experiment with 3 conditions: unburned reference, burned only, and burned/scoured. Whisker bars represent one standard error. Differing letters represent significant differences between stream conditions (Tukey's pairwise comparisons, $P<0.05$ ).

identified to the lowest taxonomic level possible (usually genus), enumerated, and placed into a drying oven for dry-weight biomass estimates. Because of recent questions raised concerning the validity of invertebrate functional feeding groups (Mihuc 1997, Dangles 2002), we placed relevant invertebrates into facultative shredder (generalist herbivore-detritivores; Mihuc 1997) and predator (Merritt and Cummins 1996) categories. Noninvertebrate organic material from the leaf bags and from the Surber samples were oven-dried $\left(48\right.$ hours at $80{ }^{\circ} \mathrm{C}$ ) and weighed to obtain dry-weight biomass estimates.

\section{Data Analysis}

We used a simple decay-rate exponential model to describe leaf litter breakdown in the 3 stream conditions. Decay-rate (line-slope) coefficients were calculated using the formula of Bärlocher (2005):

$$
M_{t}=M_{0} e^{-k t},
$$

where $M_{t}=$ biomass at time $t, M_{0}=$ initial biomass, $-k=$ exponential decay coefficient, and $t=$ time in days. An analysis of covariance (ANCOVA) was used to determine differences in breakdown rate $(-k)$ as the dependent variable over time (covariate) between stream conditions (Zar 1999).

Analyses of variance (ANOVA) were used to detect differences in macroinvertebrate abundance and biomass and physiochemical data among the 3 stream types. When necessary, these response variables were $\log (\mathrm{x}+1)$ transformed to achieve linearity and homoscedasticity. We also used ANOVA to identify differences in density of predators and several facultative shredder taxa found in the leaf bags. Finally, we used simple linear regressions and Pearson correlations to assess the relationships of the invertebrates to remaining dry-weight mass in the leaf bags, and between facultative shredders and predators (Quinn and Keough 2002).

\section{RESUlts}

Visual differences between stream types during field sampling were evident. These field observations were confirmed by significant differences in some of the physical variables we measured (Fig. 1). Dense riparian canopy over the UB stream resulted in lower levels of incident light reaching the stream's surface $\left(F_{2,147}\right.$ $=12.78, P<0.001)$ than those reaching the $\mathrm{B} / \mathrm{S}$ stream's surface. The UB stream also had cooler water temperatures $\left(F_{2,150}=49.20, P<\right.$ $0.001)$ than those recorded in the other streams. Because the riparian canopy of the UB stream was undisturbed by wildfire, we found a greater amount of benthic organic matter on that stream's substrate than on the substrate of the $\mathrm{B} / \mathrm{S}$ or $\mathrm{BO}$ streams $\left(F_{2,15}=5.88, P=\right.$ 0.013).

Leaf litter breakdown in the bags fit the decay-rate model (Fig. 2). Leaf bags in all streams had a sharp biomass reduction within the first 24 hours. However, leaf breakdown was significantly different between the streams $\left(F_{2,212}=9.54, P<0.001\right)$ : the UB system had the slowest breakdown rate $(-k=0.039)$, while the $\mathrm{B} / \mathrm{S}$ stream had the fastest breakdown rate $(-k=0.052)$. Surprisingly, the decay-rate coefficient (slope) for leaf bags in the BO stream 


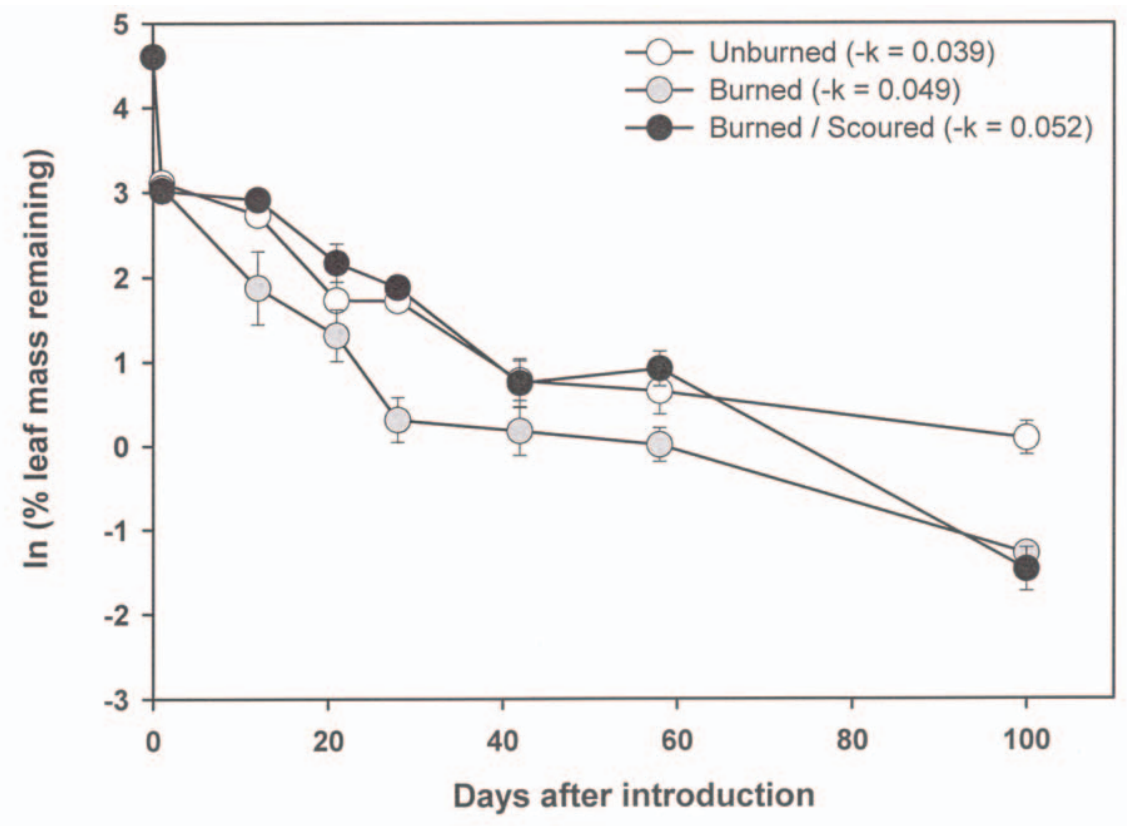

Fig. 2. Mean percent leaf biomass $(n=9)$ remaining in the bags over the time (days) since bags were first introduced into each study stream. Error bars represent one standard error. The decay coefficient $(k)$ is the slope of the best-fit line through the data points.

was significantly different from that in the other 2 stream types $\left(F_{2,211}=4.67, P<0.01\right)$. Over the first 60 days, leaf breakdown occurred more quickly in the BO stream than in the other streams. However, after the 60-day period, decay rate in the $\mathrm{B} / \mathrm{S}$ stream accelerated until termination of the experiment. In all 3 stream conditions, densities of facultative shredders were directly related to leaf biomass remaining in the bags (UB: $r^{2}=0.22, P<0.001 ; \mathrm{BO}: r^{2}=$ $\left.0.28, P<0.001 ; \mathrm{B} / \mathrm{S}: r^{2}=0.19, P=0.003\right)$.

During the course of our experiment, we found over 6000 macroinvertebrates across 46 taxonomic groups in the leaf bags. Dominant taxa varied with stream type and season (Appendix). Total invertebrate abundance in each stream type peaked between day 12 and 28, then slowly decreased after that period (Fig. 3). Lowest abundances were consistently found in the BO condition. Although there were no significant differences in total macroinvertebrate abundance or biomass between the stream types, there were significant differences between streams on individual sampling periods. The B/S condition displayed the widest variation in total abundance. On Days 1 and 12, the B/S stream had lower abundances than either of the other 2 stream conditions $(P<0.001)$; but the reverse was true on Day 28. At the end of the experiment, leaf bags from all 3 stream conditions had nearly identical invertebrate densities.

Rate of leaf litter breakdown may be affected, in part, not only by facultative shredder densities but also by densities of predatory invertebrates inhabiting each bag (Oberndorfer et al. 1984). As a result, we looked specifically at invertebrate taxa belonging to these 2 groups in our study. Facultative shredders were dominated by 5 species of insect larvae: Yoraperla brevis and Zapada oregonensis (Plecoptera), Baetis sp. and Serratella tibialis (Ephemeroptera), and Lara sp. (Coleoptera). However, only Z. oregonensis, Baetis sp., and S. tibialis occurred in sufficient numbers in each stream to analyze statistically. Densities of the facultative shredder taxa consistently differed in the $\mathrm{B} / \mathrm{S}$ condition (Fig. 4). Abundance of S. tibialis $\left(F_{2,100}=4.8, P=0.01\right)$ and $Z$. oregonensis $\left(F_{2,110}=3.3, P=0.04\right)$ were significantly lower in the $\mathrm{B} / \mathrm{S}$ stream than in the other 2 streams. Conversely, Baetis sp. was significantly higher in the B/S stream $\left(F_{2,141}=21.5, P<0.001\right)$ than in the others. 


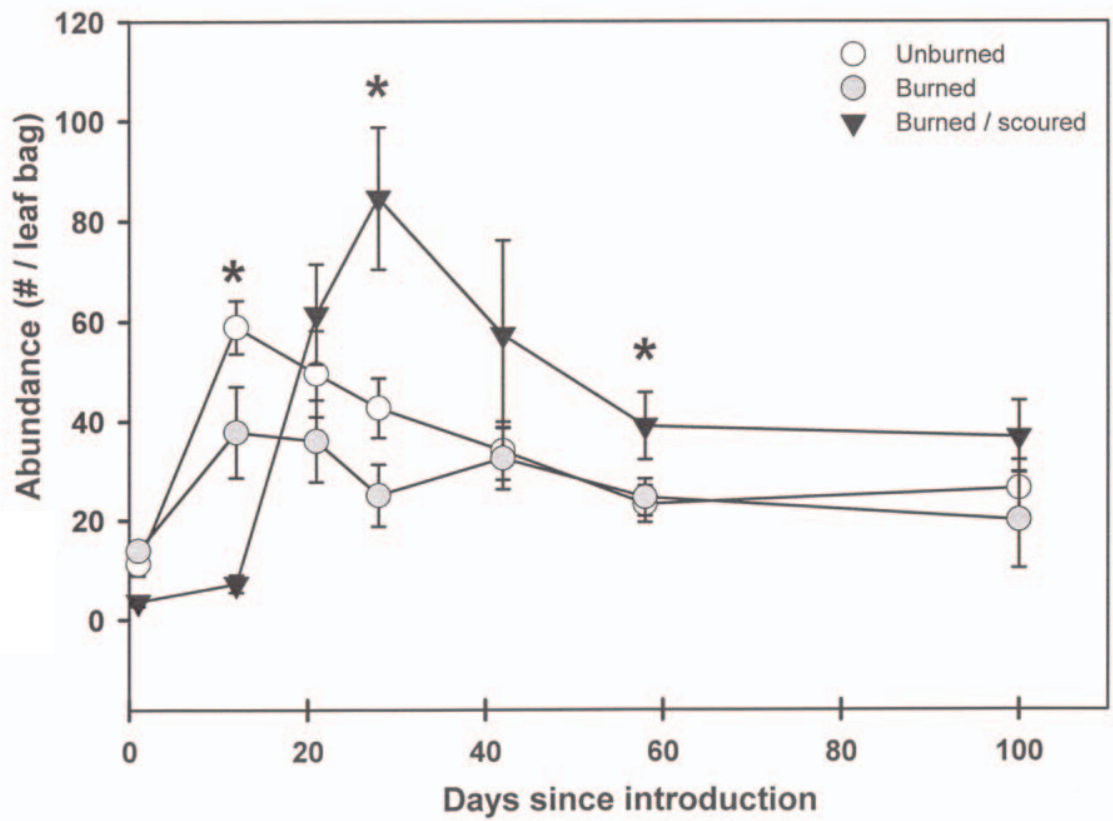

Fig. 3. Mean total abundance $(n=9)$ of macroinvertebrates collected from leaf bags in each of the treatment streams. Error bars represent one standard error. An asterisk indicates significant differences between stream conditions at $P<$ 0.05 .

Predatory macroinvertebrates in the leaf bags were dominated by 2 insect larvae: Suwallia sp. (Plecoptera: Chloroperlidae) and Rhyacophila arcopedes (Trichoptera: Hydropsychidae). Predator density was significantly higher in the UB stream than in the others $\left(F_{2,105}=17.4, P<\right.$ 0.001; Fig. 4). In each stream, predator density was correlated to pooled facultative shredder density, with the strongest correlations occurring in the $\mathrm{B} / \mathrm{S}$ condition (UB: $r=0.45$; $\mathrm{BO}: r$ $=0.40 ; \mathrm{B} / \mathrm{S}: r=0.72)$.

\section{Discussion}

We found that wildfire still influenced our study streams 10 years after the initial burn. In this study, fire-affected streams had higher water temperatures, lower amounts of benthic organic matter, and faster rates of leaf litter loss than our reference stream. Although total invertebrate density and biomass did not differ between streams, abundance of both detritivore and predatory invertebrates did.

Lower rates of leaf litter breakdown in the reference stream than in the burned streams appear to be related to physical factors influenced by the riparian vegetation and the amount and retention time of coarse particulate organic material. Because incident light levels are a good surrogate for canopy cover (Melody and Richardson 2004, Richardson and Bull 2004, Wilzbach et al. 2005), we used PAR reaching the stream surface as a measure of riparian canopy. Although no differences were found between our UB and BO streams, the composition of the riparian vegetation between these 2 was quite different. Along the UB stream, streamside vegetation consisted of mature willows and river birch forming a dense, nearimpenetrable canopy over and into the stream. Conversely, the BO stream had dense forbs and grasses arcing over the stream banks. Both riparian canopy types effectively reduced the light reaching the water's surface. Our B/S stream had very sparse vegetation of any type along its banks. PAR measurements from the B/S stream indicated that the return of the riparian vegetation is occurring more slowly than along the other 2 streams. Fire-initiated scouring removed both above- and below-ground vegetative structures, possibly slowing riparian recovery. Consequently, without an adequate riparian zone along the watercourse, the chance of continued streambed scouring after even moderate storm 


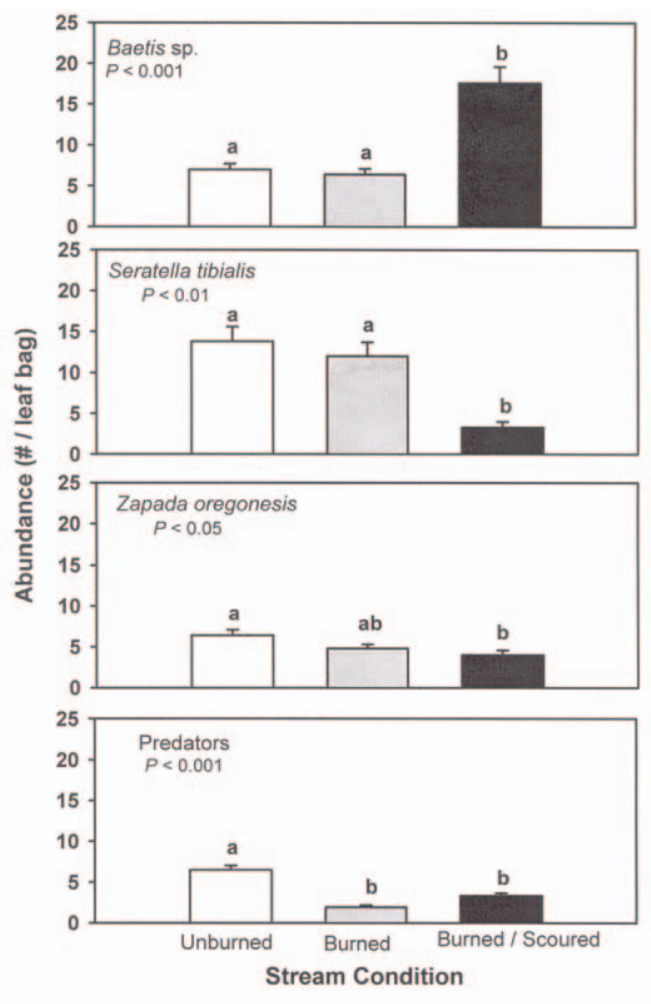

Fig. 4. Mean abundance of facultative shredding taxa and predatory insects $(n=63)$ collected from leaf bags in the study streams. Whisker bars represent one standard error. Differing letters represent significant differences between stream conditions (Tukey's pairwise comparisons, $P<0.05)$.

events increases (Benda et al. 2003, Wondzell and King 2003).

Differences in the composition and density of the riparian canopy influenced the pool of benthic organic matter $(\mathrm{BOM})$ and its retention in each stream type. In the reference stream, large amounts of BOM were present, and, coupled with the seasonal input of leaf litter, supplied the system with a constant amount of organic material. In both of the burned streams, little BOM was found. This lack of BOM may be due, in part, to low retention of organic matter. Our observations confirm previous results showing that, compared to unburned systems, burned streams have fewer woody-debris dams to entrain CPOM (Minshall et al. 1997, Gresswell 1999). With few debris dams or overhanging branches to snag and retain organic matter, this material quickly moves out of the system and becomes unavailable for biotic processing
(McIntyre and Minshall 1996). Litter retention may be as important as leaf input in determining quantities of BOM in the stream. For example, in a multiple regression analysis using data from 19 streams located throughout the United States, channel retentiveness variables explained more variability in benthic litter quantities across streams than did variables related to leaf input (Jones 1997). Leaf litter that accumulates in the stream is colonized and used by detrital invertebrates and microbial decomposers. The interplay between these organisms determines biological decomposition of organic matter in streams (Gessner et al. 1999).

In our UB stream, a well-developed riparian canopy coupled with greater amounts of BOM made available a large, constant supply of detrital material to detritivore invertebrates. Detritivores can have a pronounced effect on leaf decay rates and may time their life cycles so that high larval densities coincide with peak leaf inputs (Cummins and Klug 1979, Wallace et al. 1982). Some studies suggest that facultative shredding detritivores may switch to other food resources when leaf material becomes scarce; thus shredder densities may not be correlated to leaf litter (Mihuc and Minshall 1995, Mihuc 1997). Conversely, others have suggested that shredding invertebrates can track resource patches. Such tracking leads to shredder accumulation and accelerated breakdown of leaf packs (Rowe and Richardson 2001, Tiegs et al. 2008). Further, in studies on resource-depleted streams where leaf litter inputs are rare (clearcut catchments-Benfield et al. 2001; segments above tree line-Robinson et al. 1998), aggregation of shredders on experimental leaf packs can be massive, dramatically accelerating decomposition rates beyond those due to microbial activity alone (Baldy and Gessner 1997). In our study, we found no evidence of resource tracking by shredding detritivores. Both S. tibialis and Z. oregonensis had lower abundances in leaf bags in our B/S stream. Thus aggregations of shredding detritivores and increased leaf processing rates did not co-occur. However, numbers of Baetis sp. were higher in the $\mathrm{B} / \mathrm{S}$ stream than in the other streams, and may indicate resource switching. In postfire streams with little overhead riparian canopy, Baetis sp. densities may be related to increases in algal production. Herbivore-detritivores, like Baetis sp., with high dispersal rates via drift, multivoltine life cycles, and high reproductive 
success are well suited for survival in postfire streams (Minshall 2003). Consequently, Baetis is one of the few invertebrate taxa whose densities usually increase within 1-2 years after fire (Mihuc and Minshall 1995, Mihuc et al. 1996).

Other than detritivore invertebrates, predators may also affect leaf litter breakdown rates. Oberndorfer et al. (1984) found that predators could slow leaf decomposition rates by reducing detritivore densities (directly by consumption or indirectly by intimidation). However, in our study, predators did not appear to have this effect on detritivore taxa or on leaf litter breakdown. The difference in these findings may be due to the sampling design. Whereas Oberndorfer et al. (1984) placed leaf packs in cages that prevented predators from entering or leaving the cage (depending on the treatment), we used mesh bags that allowed unrestricted movement in and out of the bags by all invertebrates. If detritivore densities decreased within a bag, predators could exit and hunt for prey elsewhere. In contrast, in predator-free bags, detritivores would accumulate until their numbers increased enough to attract predators.

Invertebrate community composition and leaf processing rates should be linked to changes in the catchment basin drained by the stream (Hynes 1975). However, few studies have actually demonstrated that leaf breakdown rates are associated with landscape-level change. Sponseller and Benfield (2001) found that leaf breakdown showed little response to wholecatchment land use. Likewise, invertebrate community composition or leaf decomposition rate did not differ between streams draining forested, agricultural, or logged catchments (Bird and Kaushik 1992, Stone and Wallace 1998). However, in our study, we did find differences in leaf processing rates, which may be related to drainage basin characteristics. Wildfire, by removing a stream's riparian zone, decreases leaf litter inputs and woody debris snags and alters invertebrate community composition (Minshall et al. 1997, Minshall 2003, Robinson et al. 2005). In burned areas, continued scouring/reworking of the channel-coupled with erosional loss of streamside vegetation during storm eventswould keep the stream system in an unstable state. In turn, faster current velocities and lower CPOM retention would increase leaf loss due to physical breakdown, mechanical fragmentation, and increased rates of export (Tuchman and King 1993). Within this harsh environment, low food resources would further limit densities of facultative shredders. Conversely, in unburned streams, greater riparian inputscoupled with higher CPOM retention on the substrate and slower current velocities-would lead to a stable environment. Litter processing rates would depend more on biological mechanisms and less on physical ones (sensu Peckarsky 1983). In these unburned streams, predators may limit detritivore densities; thus, detritivores may show only a functional response to increasing leaf litter, and higher inputs of CPOM may not lead to an increase in the litter decomposition rate. In wildfire-affected streams, physical mechanisms may have a greater effect on leaf loss than on biological processes. In our study, differences in CPOM decomposition were still evident some 10 years after the fire.

In summary, wildfire-coupled with fireinduced debris flow-can be a major disturbance, with impacts that are evident years after the initial burn. In the intermediate to longterm temporal scale, wildfire can alter diets of stream fish (Koetsier et al. 2007), influence the distribution of fish and amphibians (Dunham et al. 2007), alter ecosystem metabolism (Tuckett 2007), affect leaf litter processing rates (this study), and reconfigure a stream's physical and geomorphological characteristics (Benda et al. 2003, Meyer and Pierce 2003, Robinson et al. 2005). To best manage fish, wildlife, and timber resources, an understanding of how wildfire affects biotic processes over the long term is essential. Too often, studies on the effects of wildfire on streams use "burn" and "reference" as the treatment dichotomy. Like Dunham et al. (2007) and Koetsier et al. (2007), our data suggest that, if the appropriate geology occurs, a third category should be included: burnedthen-scoured stream habitat. Including this third group may reduce the variability of response signatures used to determine biotic recovery from wildfire. In turn, this third group could lead to a clearer understanding of stream resilience and recovery from wildfire.

\section{ACKNOWLEDGMENTS}

This study was supported by the National Research Initiative of the USDA Cooperative State Research, Education, and Extension Service (grant number 2003-35101-13682) and by the Dan Montgomery Foundation for ecological study. We thank D. Nagel (USFS) for GIS layer 
maps, and A. Rosenberger (University of Alaska) and J. Dunham (USGS) for many thoughtful discussions on study-site selection and the role of fire in forested ecosystems. We also thank Mark C. Belk and 3 anonymous reviewers, whose comments made this a better manuscript.

\section{Literature Cited}

BALDY, V.V., AND M.O. GESSNER. 1997. Towards a budget of leaf litter decomposition in a first-order woodland stream. Comptes Rendus de l'Académie des Sciences Série III 320:747-758.

BÄRLOCHER, F. 2005. Leaf mass loss estimated by litter bag technique. Pages 37-42 in M.A.S. Graca, F. Bärlocher, and M.O. Gessner, editors, Methods to study litter decomposition: a practical guide. Springer, Dordrecht, The Netherlands.

Benda, L., D. Miller, P. Biglow, and K. Andras. 2003. Effects of post-wildfire erosion on channel environments, Boise River, Idaho. Forest Ecology and Management 178:105-119.

Benfield, E.F., J.R. Webster, J.L. TANK, AND J.J. Hutchens. 2001. Long-term patterns in leaf breakdown in streams in response to watershed logging. International Review of Hydrobiology 86:467-474.

BIRD, G.A., AND N.K. KAUSHIK. 1992. Invertebrate colonization and processing of maple leaf litter in a forested and an agricultural reach of a stream. Hydrobiologia 234:65-77.

Cummins, K.W., AND M.J. KLug. 1979. Feeding ecology of stream invertebrates. Annual Review of Ecology and Systematics 10:147-172.

DangLES, O. 2002. Functional plasticity of benthic macroinvertebrates: implications for trophic dynamics in acid streams. Canadian Journal of Fish and Aquatic Sciences 59:1563-1573.

DraKe, J.A. 1990. Communities as assembled structures: do rules govern patterns? Trends in Ecology and Evolution 5:159-164.

Dunham, J.B., A.E. Rosenberger, C.H. Luce, and B.E. Rieman. 2007. Influences of wildfire and channel reorganization on spatial and temporal variation in stream temperature and the distribution of fish and amphibians. Ecosystems 10:335346.

DwiRe, K.A., And J.B. Kauffman. 2003. Fire and riparian ecosystems in landscapes of the western USA. Forest Ecology and Management 178:61-74.

Gessner, M.O., E. Chauvet, and M. Dodson. 1999. A perspective on leaf litter breakdown in streams. Oikos 85:377-384.

Gordon, N.D., T.A. McMahon, B.L. Finlayson, C.J. GipPEL, AND R.J. Nathan. 2004. Stream hydrology: an introduction for ecologists. 2nd edition. John Wiley \& Sons, Ltd., West Sussex, England.

Gresswell, R.E. 1999. Fire and aquatic ecosystems in forested biomes of North America. Transactions of the American Fisheries Society 128:193-221.

HAWKINS, C.P. 1986. Pseudo-understanding of pseudoreplication: a cautionary note. Bulletin of the Ecological Society of America 67:184-185.

Hynes, H.B.N. 1975. The stream and its valley. Internationale Vereinigung für theoretische und angewandte Limnologie 19:1-15.
JoNES, J.B. 1997. Benthic organic matter storage in streams: influence of detrital import and export, retention mechanisms, and climate. Journal of the North American Benthological Society 16:109-119.

Koetsier, P., Q. TucketT, and J. White. 2007. Present effects of past wildfires on the diets of stream fish. Western North American Naturalist 67:429-438.

McIntyke, M.J., and G.W. Minshall. 1996. Changes in transport and retention of coarse particulate organic matter in streams. Pages 59-75 in J.M. Greenlee, editor, The ecological implications of fire on Greater Yellowstone Ecosystem. International Association of Wildland Fire, Fairfield, WA.

Megahan, W.F. 1983. Hydrologic effects of clearcutting and wildfire on steep granitic slopes in Idaho. Water Resources Research 19:811-819.

Megahan, W.F., and G.L. Ketcheson. 1996. Predicting downslope travel of granitic sediments from forest roads in Idaho. Water Resource Bulletin 32:371-382.

Melody, K.J., and J.S. Richardson. 2004. Responses of invertebrates and algae of a boreal coniferous forest stream to experimental manipulation of leaf litter inputs and shading. Hydrobiologia 519:197-206.

Merritt, R.W., and K.W. Cummins. 1996. An introduction to the aquatic insects of North America. 3rd edition. Kendall/Hunt Publishing Company, Dubuque, IA.

Meyer, G.A., AND J.L. PierCe. 2003. Climatic controls on fire-induced sediment pulses in Yellowstone National Park and central Idaho: a long-term perspective. Forest Ecology and Management 178:89-104.

Minuc, T.B. 1997. The functional trophic role of lotic primary consumers: generalist versus specialist strategies. Freshwater Biology 37:455-462.

Minuc, T.B., AND G.W. Minshall. 1995. Trophic generalists vs. trophic specialists: implications for food web dynamics in post-fire streams. Ecology 76:2361-2372.

Minuc, T.B., G.W. Minshall, and C.T. Robinson. 1996. Response of benthic macroinvertebrate populations in Cache Creek, Yellowstone National Park to the 1988 wildfires. Pages 83-94 in J.M. Greenlee, editor, The ecological implications of fire on Greater Yellowstone Ecosystem. International Association of Wildland Fire, Fairfield, WA.

MinshalL, G.W. 2003. Responses of stream benthic macroinvertebrates to fire. Forest Ecology and Management 178:155-166.

Minshall, G.W., J.T. Brock, and J.D. Varley. 1989. Wildfire and Yellowstone's stream ecosystems: a temporal perspective shows that aquatic recovery parallels forest succession. BioScience 39:707-715.

Minshall, G.W. C.T Robinson, and D.E. Lawrence. 1997. Postfire responses of lotic ecosystems in Yellowstone National Park, USA. Canadian Journal of Fisheries and Aquatic Sciences 54:2509-2525.

Minshall, G.W., T.V. Royer, and C.T. Robinson. 2004. Stream ecosystem response to fire: the first ten years. Pages 165-188 in L.L. Wallace, editor, After the fires: the ecology of change in Yellowstone National Park. Yale University Press, New Haven, CT.

Oberndorfer, R.Y., J.V. MCARThur, J.R. BARnes, and J. DixON. 1984. The effects of invertebrate predators on leaf litter processing in an alpine stream. Ecology 65:1325-13331.

Paul, M.J., J.L. Meyer, and C.A. Couch. 2006. Leaf breakdown in streams differing in catchment land use. Freshwater Biology 51:1684-1695. 
Peckarsky, B.L. 1983. Biotic interactions or abiotic limitations? A model of lotic community structure. Pages 303-323 in T.D. Fontaine and S.M. Bartell, editors, Dynamics of lotic ecosystems. Ann Arbor Science Publishers, Ann Arbor, MI.

Quinn, G.P., AND M.J. KeOugh. 2002. Experimental design and data analysis for biologists. Cambridge University Press, Cambridge, England.

Richardson, J.S., AND J.P. BuLl. 2004. Establishing light as a causal mechanism structuring stream communities in response to experimental manipulation of riparian buffer widths. Journal of the North American Benthological Society 23:542-555.

Rieman, B.E., and J. Clayton. 1997. Wildfire and native fish: issues of forest health and conservation of sensitive species. Fisheries 22:6-15.

Robinson, C.T., M.O. Gessner, AND J.V. Ward. 1998. Leaf breakdown and associated macroinvertebrates in alpine glacial streams. Freshwater Biology 40:215-228.

Robinson, C.T., U. Uehlinger, and G.W. Minshall. 2005. Functional characteristics of wilderness streams twenty years following wildfire. Western North American Naturalist 65:1-10.

Rowe, L., And J.S. Richardson. 2001. Community responses to experimental food depletion: resource tracking by stream invertebrates. Oecologia 129:473-480.

Spencer, C.N., AND F.R. Hauer. 1991. Phosphorus and nitrogen dynamics in streams during a wildfire. Journal of the North American Benthological Society 10:24-30.

SPONSElLER, R.A., AND E.F. BEnFIELD. 2001. Influences of land use on leaf breakdown in southern Appalachian headwater streams: a multiple-scale analysis. Journal of the North American Benthological Society 20:44-59.

STONE, M.K., AND J.B. WALLACE. 1998. Long-term recovery of a mountain stream from clearcut logging: the effects of forest succession on benthic invertebrate community structure. Freshwater Biology 39:151-169.

Tiegs, S.D., F.D. Peter, C.T. Robinson, U. Uehlinger, And M.O. Gessner. 2008. Leaf decomposition and invertebrate colonization responses to manipulated litter quantity in streams. Freshwater Biology 27: 321-331.

Tuchman, N.C., AND R.H. KING. 1993. Changes in mechanisms of summer detritus processing between wooded and agricultural sites in a Michigan headwater stream. Hydrobiologia 268:115-127.

TucketT, Q.M. 2007. The effect of wildfire and debris flows on small headwater stream ecosystems in central Idaho. Master's thesis, Boise State University, Boise, ID.

Vannote, R.L., G.W. Minshall, K.W. Cummins, J.R. SeDELL, AND C.E. Cushing. 1980. The river continuum concept. Canadian Journal of Fisheries and Aquatic Sciences 37:130-137.

Vieira, N.K.M., W.H. Clements, L.S. Guevara, and B.F. JACOBS. 2004. Resistance and resilience of stream insect communities to repeated hydrological disturbance after a wildfire. Freshwater Biology 49: 1243-1259.

Wallace, J.B., J.R. Webster, and T.F. Cuffney. 1982. Stream detritus dynamics: regulation by invertebrate consumers. Oecologia 53:197-200.

Webster, J.R., AND E.F. BENFIELD. 1986. Vascular plant breakdown in freshwater ecosystems. Annual Review of Ecology and Systematics 17:567-594.

Wilzbach, M.A., B.C. Harvey, J.L. White, and R.J. NAKAмOTO. 2005. Effects of riparian canopy opening and salmon carcass addition on the abundance and growth of resident salmonids. Canadian Journal of Fisheries and Aquatic Sciences 62:58-67.

Wondzell, S.M., AND J.G. KING. 2003. Postfire erosional processes in the Pacific Northwest and Rocky Mountain regions. Forest Ecology and Management 178: 75-87.

ZAR, J.H. 1999. Biostatistical analysis. 4th edition. Prentice Hall, Upper Saddle River, NJ.

Received 7 August 2009 Accepted 3 December 2009 
APPENDIX. Relative abundance (\%) of macroinvertebrates collected in the leaf bags from 3 stream conditions during the study period (July-October 2004).

\begin{tabular}{|c|c|c|c|}
\hline Taxa & Beaver Creek (UB) & Hungarian Creek (BO) & Trapper Creek $(\mathrm{B} / \mathrm{S})$ \\
\hline \multicolumn{4}{|l|}{ EPHEMEROPTERA (MAYFLIES) } \\
\hline Ameletus cooki & $*$ & 0.1 & $*$ \\
\hline Baetis sp. & 17.9 & 21.7 & 33.5 \\
\hline Cinygmula sp. & $*$ & 0.4 & $*$ \\
\hline Drunella doddsi & 0.1 & $*$ & $*$ \\
\hline Drunella flavia & 1.4 & 0.5 & 0.1 \\
\hline Epeorus longimanus & 0.2 & $*$ & $*$ \\
\hline Heptagenia sp. & 1.2 & 0.6 & 0.6 \\
\hline Paraleptophlebia sp. & 1.4 & 1.0 & 1.1 \\
\hline Serratella tibialis & 33.4 & 37.0 & 1.5 \\
\hline \multicolumn{4}{|l|}{ Plecoptera (STONEFlies) } \\
\hline Acroneuria sp. & $*$ & $*$ & 0.1 \\
\hline Alloperla sp. & $*$ & $*$ & 0.1 \\
\hline Capnia sp. & 0.1 & $*$ & $*$ \\
\hline Claassenia sp. & $*$ & $*$ & 0.1 \\
\hline Suwallia sp. & 5.0 & 0.8 & 0.6 \\
\hline Sweltsa sp. & 0.1 & $*$ & $*$ \\
\hline Yoroperla brevis & 0.8 & 0.3 & $*$ \\
\hline Zapada oregonesis & 15.7 & 11.6 & 5.1 \\
\hline \multicolumn{4}{|l|}{ TRICHOPTERA (CADDISFLIES) } \\
\hline Arctopsyche sp. & $*$ & $*$ & 3.7 \\
\hline Brachycentrus americanus & $*$ & $*$ & 0.6 \\
\hline Dicosmoecus sp. & $*$ & $*$ & 0.1 \\
\hline Glossosoma sp. & 0.2 & 0.1 & $*$ \\
\hline Hydropsyche sp. & 0.7 & 3.5 & 17.1 \\
\hline Lepidostoma sp. & $*$ & 0.1 & 0.4 \\
\hline Limnephilius sp. & 0.3 & 0.1 & 0.3 \\
\hline Micrasema sp. & 0.1 & 0.1 & $*$ \\
\hline Neophylax sp. & 0.2 & $*$ & $*$ \\
\hline Polycentropus sp. & 0.2 & $*$ & 0.2 \\
\hline Rhyacophila sp. & 10.7 & 9.6 & 3.8 \\
\hline \multicolumn{4}{|l|}{ COLEOPTERA (BEETLES) } \\
\hline Lara sp. & 0.3 & 1.9 & 0.4 \\
\hline Narpus sp. & 0.1 & 0.7 & $*$ \\
\hline Optioservus sp. & 2.6 & 4.8 & 18.4 \\
\hline \multicolumn{4}{|l|}{ DiPTERA (TRUE FLIES) } \\
\hline Chironomidae & 2.8 & 0.6 & 2.3 \\
\hline Dixa sp. & $*$ & 0.1 & $*$ \\
\hline Hexatoma sp. & $*$ & 0.1 & $*$ \\
\hline Simulium sp. & 4.0 & 3.8 & 9.6 \\
\hline \multicolumn{4}{|l|}{ OTHER INVERTEBRATES } \\
\hline Annelida & 0.1 & 0.1 & $*$ \\
\hline Hydracarina & $*$ & 0.1 & $*$ \\
\hline TOTAL NUMBER & 2107 & 1569 & 2254 \\
\hline
\end{tabular}

*Less than $0.01 \%$ collected 